\title{
Mapping the Relation between Emotional Intelligence and Managerial Effectiveness at Workplace: An Overview
}

\author{
Nidhi Chadha ${ }^{1} *$
}

\section{ABSTRACT}

The present study attempts to ascertain the importance of relationship between emotional intelligence and managerial effectiveness. Though a great deal of attention has been paid to this area in the last few decades, but the subject still requires more research as the business scenario is continuously changing and is prone to unpredictable challenges. India being a rapidly growing economy and largely depends upon its human capital and so increasing attention is being directed towards improving emotional intelligence and managerial effectiveness. Thus, this study is in a growing line of research and can provide valuable insight especially for managers as it can help in planning and executing human resource policies aimed at augmenting the effectiveness of managers.

Keywords: Emotional Intelligence, Managerial Effectiveness, Competency, Ability

With an increasing 'cut throat' competition and dynamic business environment around the globe, organizations require a team of managers to run day to day operations (Boyatzis 1982). Managers play a significant role in the development, formulation, and execution of the organization's long term as well as short term strategies that determine corporate success (AlMadhouni \& Analoui 2004). Indeed, managers are dynamic and the life giving elements in every business and without them the resources cannot be converted into high production (Drucker 1967). With increased dependency of business on information technology, managers are required to sort out new ways to facilitate organizational production and sustainable self growth. What differentiates surviving organizations from others (Sinclair-Hunt \& Simms 2005), that have not been able to tackle 'tough times', is the performance and effectiveness of its executive. Consequently, management may be viewed as a special kind of leadership in which the achievement of the organizational goal is vital and managers strive to operate in a situation with optimum performance outcomes. The performance of a manager and how effectively he/she would operate a situation is related to many variables from an individual to an organizational dimension (Hamlin and Serventi 2008, Bao 2009).

The role of the manager has never been as important or demanding as it is today. Managers at all levels must deliver consistent, sustainable results and get things done day to day with fewer resources. There is an increased emphasis on maintaining employee morale and high levels of

\footnotetext{
${ }^{1}$ Post Graduate Government College- Sector 11, Chandigarh

*Corresponding Author

(C) 2015 I N Chadha; licensee IJIP. This is an Open Access Research distributed under the terms of the Creative Commons Attribution License (http://creativecommons.org/licenses/by/2.0), which permits unrestricted use, distribution, and reproduction in any Medium, provided the original work is properly cited.
} 
productivity in an increasingly complex and changing business environment. Also, managers must ensure that the right people with the right skills are in the right roles. Growing an effective manager is not something an organization does on the spur of the moment expecting results overnight. It takes commitment and strategy. It requires a solid foundation with proper planning, use of the organizational culture, proper training methods and individuals with the right stuff, potential, and wanting to excel in world-class leadership.

Conceptualization of Emotional Intelligence: There are a plethora of prominent authors who have defined "Emotional Intelligence" through varied perspectives, delineated below are some of which have been proposed recently:

- Hein (2007) defined "Emotional Intelligence is the innate potential to feel, use, communicate, recognize, remember, describe, identify, learn from, manage, understand, and explain emotions".

- As per Sims-Vanzant (2007) emotional intelligence is defined as, "the ability to recognize one's own feelings and those of others, the capacity to motivate others, and the ability to manage one's own emotions and relationships".

- Petrides (2009) defined Emotional Intelligence as a self-perceived grand ability to identify, assess, manage and control the emotions of one's self, of others, and of groups.

- BNET Business Dictionary (2011) described Emotional Intelligence as the ability to perceive and understand personal feelings and those of others. Emotional Intelligence means recognizing emotions and acting on them in a reflective and rational manner which involves self-awareness, empathy, and self-restraints.

- More recently, Multi Health Systems (2012) defined Emotional Intelligence as "a set of emotional and social skills that influence the way we perceive and express ourselves, develop and maintain social relationships. Cope with challenges, and use emotional information in an effective and meaningful way".

Common themes in the conception of Emotional Intelligence: An attempt has been made to pull together common themes from various conceptualizations of emotional intelligence given by numerous researchers, which are pinpointed below:

Couple of writers defined emotional intelligence as an ability or tendency to perceive, understand and regulate one's own feelings and emotions and be sensitive enough to perceive and recognize others emotions and feelings as well (Mayer \& Salovey (1990), Goleman (1998a), Schutte et al. (1998), Dulewicz \& Higgs (1999), Nadler (2007), Sims-Vanzant (2007), Petrides (2009), Bradberry and Greaves (2009) and BNET Business Dictionary (2011). Also, same set of researchers who classified emotional intelligence as an ability or tendency to understand and regulate one's own emotions and that of others also emphasized on a very important facet i.e. interpersonal aspect of emotional intelligence - develop, maintain and enhancement of social relationships (Sims-Vanzant (2007) and Multi Health Systems (2012). According to another stream of researchers i.e. Bar-On (2000), Orioli \& Cooper (2002) and Singh (2003) - Emotional 
intelligence refers to a set of competencies and skills to respond to an array of emotional stimuli and succeed from environmental demands and pressures.

Conceptualization of Managerial Effectiveness: Managerial effectiveness has been defined differently over the past decades, by different authors; each gave a different definition in their works, of which few recent are presented below:

- Metts (2007) stated that effectiveness could be assessed by focusing on what managers do (focusing on behaviour and action of managers), and what managers achieve (focusing on performance results of managers).

- Drucker (1967 cited in Analoui et al., 2010) defined effectiveness as a set of skills required to get the right things done and he considered managerial effectiveness to be a function of a manager's competences including: time management, resultorientation, building on strength, concentrating on a few major areas and making effective decisions.

- Rana et al., (2011) stated that managers are said to be effective if they use and manage their resources in different and difficult situations appropriately and select the correct approaches to achieve the goals of their jobs.

- Robbins and Coutler (2012) defined effectiveness in terms of ends, results, consequences or attainment of organizational goals

Common themes in the conception of Managerial Effectiveness: Comparing the different definitions of managerial effectiveness given above, it can be seen that they have many common attributes, which are pinpointed below:

According to one set of researchers i.e. Drucker (1967), Boyatzis (1982), Gupta (1996), Wang (2011) - Effectiveness is concerned with the managerial qualities and set of skills to carry out managerial function, activities required of his position. As per Certo (2006), Metts (2007), Rana et al.(2011) \& Buter (2012) - Managerial effectiveness occurs when a manager's effort results in the ongoing satisfying of organizational goals. Also, many writers defined managerial effectiveness as the extent to which the stated goals of an organization are achieved (Hatten, 2012; Certo and Certo, 2012; Abdul-Azeem and Fatima, 2012). Lastly, another stream of researchers Broide \& Bennett (1979), Garg \& Handa (1992), Robbins \& Coutler (2012) proposed that the effectiveness of a manager should be defined by what results and consequences a manager achieves or attains and the extent to which he goes beyond what is normally required of him.

\section{Emotional Intelligence and Managerial Effectiveness at Workplace}

Goleman (1995) asserted that "Emotional Intelligence is twice as important as IQ and technical skills as emotional intelligence assists people in teamwork, in cooperation, and in learning how to work more effectively that enables to achieve better outcomes in leadership, management, supervision, and relationship building. Hence, teaching EQ (soft) skills at work is more important than technical skills. Further, Goleman (2001b) extended his theory to the workplace 


\section{Mapping the Relation between Emotional Intelligence and Managerial Effectiveness at Workplace: An Overview}

and offered emotional intelligence as a theory of performance which predicts personal effectiveness in the workplace, particularly in leadership behaviors. In a later book "Social Intelligence", Goleman (2006) subsumed 25 competencies of emotional intelligence under the five main domains i.e., self-awareness, self-regulation, motivation, empathy, and social skills.

Emotional Intelligence has also been claimed to be an important factor in managerial effectiveness. George (2000) used the Salovey, Mayer, and Caruso four branch model of Emotional Intelligence as a heuristic framework for outlining the importance of Emotional Intelligence in managerial effectiveness. George asserts that by accurately identifying how followers feel, managers better appraise and influence followers' emotions so they are supportive of manager's goals and objectives, thus insuring a shared vision. Managers can use intense emotions as signals to direct their attention to issues in need of immediate attention, and can use emotions to prioritise demands. They can also better anticipate how well their followers will react to different circumstances and changes.

Therefore, recruiting effective managers possessing attitudes and behaviours like receptivity to feedback, self disclosure, action orientation, perceptiveness (Pareek, 2002) and with high Emotional Intelligence can generate excitement, enthusiasm, and optimism in the work environment and also be able to maintain an atmosphere of cooperation and trust through the development of high quality interpersonal relations. Further, such managers can effectively instill in others an appreciation of the importance of work activities and convey the message to their followers that they are optimistic about their personal contributions.

It is vital to mention here that, the above insights can be understood and linked with the existing theoretical conceptualizations. These theoretical orientations support the line of reasoning concerning the relationship of emotional intelligence and managerial effectiveness. Thus, the present study makes a humble contribution by adding an important aspect to the existing literature i.e. by mapping the significance of relationship between emotional intelligence and managerial effectiveness.

- Boyatzis (1982) proposed a contingency model of management effectiveness which postulated a "best fit" between the individual, job demands and the organizational environment would predict effectiveness. Maximum performance is believed to occur when the manager's capability or talent is consistent with the needs of the job demand and organizational environment. According to this model an individual's competencies is represented in three clusters i.e. emotional, cognitive and social. Competencies are certain characteristics or abilities of an individual that enable them to demonstrate appropriate specific actions. Emotional intelligence competencies include self awareness and self management competencies such as emotional self awareness and emotional self control.

- Hay/McBer (1997) offered competencies which are found to be critical for effective managers and it includes achievement orientation, developing others, directiveness, impact and influence, interpersonal understanding, organizational awareness and team 
leadership. The competency of 'developing others' and 'interpersonal understanding' aligns well with emotional intelligence. These competencies reflects a manager's ability to recognize, understand and use emotional information about oneself and others that leads to or causes effective or superior performance.

- The theoretical orientation i.e. 'View on Management Skills' given by Ivancevich \& Matteson (1999) clearly emphasizes as to which skills managers require to be effective in managing their organizational units. They presented seven categories of management skills that they regard as important in the performance of managerial roles. Amongst the seven, human relations and communication skills aligns well with the concept of emotional intelligence. Human relations skills enhance a manager's ability to manage group dynamics, encourage cooperation and resolve conflicts. Communication skills involve the ability to communicate in ways that other people understand, and to seek and use feedback from employees to ensure that one is understood. Since communication is effected in different forms- such as written and oral transmission of common understanding- a manager needs to hone his or her skills in this area, in order to be effective in managerial performance.

- Further, Leslie et al (2002) proposed five sets of dimensions which contribute to the overall effectiveness of managers. The most important dimension which goes parallel with emotional intelligence is - 'Interpersonal relationships'. This dimension seeks to cover how the managers work in a team, the way they represent and handle relationships inside the organization.

- The generic framework by Hamlin (2007c) on managerial and leadership effectiveness explains the 'behavioral criteria for effective managers'. The effective behavioral criteria of 'genuine care and concern for staff', 'open and personal management approach', 'communicates and consults well with staff' is found to be parallel with the emotional intelligence construct.

- Lastly, Human Resource Management, United Nations (2009) explained three sets of competencies which are fundamental to managerial effectiveness i.e. emotional, conceptual and technical. Emotional competencies implies for managing oneself and one's relationships with others. Emotionally competent managers are self aware manage their own emotions and recognize the impact they have on others. They create a positive, energetic work environment, in which they and the people they work with are inspired to contribute their best efforts.

\section{Final Remark!}

Prior research has explored the concept of emotional intelligence, which is the ability both to know one's own emotions and to read others' emotions as well but recent researches reveal that emotional intelligence plays a significant part in assisting managers to manage dynamic change in business environment (Rafique et.al, 2011) and also, it needs to be considered in the selection and placement process for managerial effectiveness to be guaranteed (Akintayo, 2010; Ashraf \& Khan, 2011). As a result, it is the need of the hour to explore the emerging issues of emotional intelligence. 


\section{REFERENCES}

Abdul-Azeem, M., Fatima, S., (2012). Factors favoring managerial effectiveness: a study of select public \& private sector organizations. International Journal of Business Economics \& Management Research, 2(1), pp.1-27.

Akintayo, D.I. (2010). Managerial Effectiveness: Impact of Emotional Intelligence and Work Family Role Conflict in work Organizations in Nigeria, Eastern Africa Social Science Research Review. Volume 26, Number 1, 23-40.

Al-Madhouni, M. I. \& Analoui, F. (2004). Developing SME managers under fire: Negotiating obstacles and weaknesses in Palestine. Journal of Management Development, 23(5), 479495.

Ashraf, F. \& Khan, F.A. (2012). Impact of emotional intelligence on managerial effectiveness in health care: Empirical evidence from Pakistan, African Journal of Business Management Vol. 6(11), pp. 3941-3953.

Bao, C. (2009). Comparison of public and private sector managerial effectiveness in China: a three-parameter approach. Journal of Management Development, 28(6), 533-541.

Bar-On, R. (2000). Emotional and social intelligence: Insights from the Emotional Quotient Inventory (EQ-i). In Reuven Bar-On and James D.A. Parker (Eds.), Handbook of emotional intelligence: Theory, development, assessment and application at home, school and in the workplace, (pp. 363-388). San Francisco: Jossey-Bass.

Boyatzis, R. (1982). The competent manager: A model of effective performance. New York, NY: Wiley.

Bradberry, T., \& Greaves, J. (2009). Emotional Intelligence 2.0. San Francisco: Publishers Group West.

Broide, M., \& Bennett, R. (1979). Perspective on managerial effectiveness. Slough: Valley Regional Management Center.

Buter, S.G.H., (2012). Does culture explain managerial effectiveness: a qualitative study in Mexico whether culture is influencing differences in managerial effectiveness between Mexican managers and western expatriates. Master. University of Twente. Available at: $<$ http://essay.utwente.nl/61445/> [Accessed 30 October 2013] 6/9/2013 21:13.

Certo, S.C. (2006). Principles of Modern Management, Functions and System, $3^{\text {rd }}$ Edition p. 140.

Certo, S. C., Certo, S. T., (2012). Modern management: concepts and skills. 12th ed. Upper Saddle River, NJ: Prentice Hall.

Drucker, P. F. (1967). The effective executive: Effectiveness can be learned. Sussex: Book Print Limited Crawley.

Dulewicz, V. \& Higgs, M. (1999). Can emotional intelligence be developed? International Journal of Human Resource Management, 15(1), 95-111.

Garg, S. and Handa, S. (1992). Dynamics of Managerial Effectiveness. Jaipur. Arihant publishers.

George, J. M. (2000). Emotions and leadership. The role of emotional intelligence. Human Relations, 53 (8), 1027-1044.

Goleman, D. (1995). Emotional intelligence. New York: Bantam Books.

Goleman, D. (1998a). Working with emotional intelligence. New York:Bantam Books.

Goleman, D. (2001b). Emotional Intelligence: Issues in Paradigm Building. In D. Goleman (Ed.), The Emotionally Intelligent Workplace: How to Select for, Measure, and Improve 


\section{Mapping the Relation between Emotional Intelligence and Managerial Effectiveness at Workplace: An Overview}

Emotional Intelligence in Individuals, Groups, and Organizations (pp. 13-26). San Francisco: Jossey-Bass.

Goleman, D. (2006). Emotional Intelligence. New York: Bantam Dell.

Gupta, S. (1996). Managerial Effectiveness: Conceptual Framework and Scale Development, Indian Journal of Industry Relations, 31(3), 392-401.

Hamlin, R. G., \& Serventi, S. A. (2008). Generic behavioral criteria of managerial effectiveness: An empirical and comparative case study of UK local government. Journal of European Industrial Training, 32(4), 285-302.

Hamlin, R.G. (2007c). Generic behavioural criteria of manager and managerial leader effectiveness: Generating HRD related 'general knowledge' through Mode 2 research. Paper presented at the UFHRD/AHRD Eighth International Conference on HRD Research and Practice Across Europe, Oxford Brookes University, Oxford, June.

Hatten, T. S., (2012). Small Business Management: Entrepreneurship and Beyond. 5th ed. Mason, OH: South-Western Cengage Learning.

Hay/McBer, (1997). Research and Innovation Group. In Goleman, D. (Eds.), Emotional intelligence. New York: Bantam Books.

Hein, S. (2007). EQI. Retrieved November 13, 2009, from http://eqi.org/eidefs.htm \#Introduction.

Human Resource Management (2009). Profile of an effective manager: For managerial excellence in the United Nations. Division for organizational development.

Ivancevich, J., \& Matteson, M. (1999). Organizational behavior and management ( $6^{\text {th }}$ Ed.). New York: McGraw-Hill.

Leslie, J., Dalton, M., Ernst, C., \& Deal, J., (2002). Success for the new global manager: How to work across distances, countries, and cultures. San Francisco: Jossey-Bass and Center for Creative Leadership. European journal of work and organizational psychology.

Mayer, J. D., \& Salovey, P. (1990). Emotional Intelligence. Imagination, Cognition and Personality, 9(3), 185-211.

Metts, G. A. (2007). Measuring the effectiveness of managerial action in SMEs: An empirical analysis of management's response to industry competitive forces. Management Research News, 30(12), 892-914.

Nadler, R. S. (2007) Leadership Keys and Field Guide: Keys to Great Leadership. Santa Barbara: Psyccess Press

Orioli, E. \& Cooper, R. (2002). About Emotional Intelligence (Online). Retrieved on September 23, 2002 from www.gmetricseq.com.

Pareek, U. (2002). Training Instruments in HRD and OD. New Delhi: Tata McGraw-Hill Edition, 537-547.

Petrides , K. V. (2009). Technical manual for the Trait Emotional Intelligence Questionnaires (TEIQue) . London : London Psychometric Laboratory .

Rafiq, M., Naseer, Z., \& Ali, B. (2011). Impact of Emotional Intelligence onOrganizational Learning Capability. International Journal of Academic Research.. 3(4).321-325.

Rana, G., Garg, P., \& Rastogi, R., (2011). Effect of Justice Perception on Managerial Effectiveness. The IUP Journal of Organizational Behavior, 10(2), pp.7-20.

Robbins, S. P. \& Coutler M., (2012). Management. 11th ed. Upper Saddle River, NJ: Prentice Hall. 
Schutte, N. S., Malouff, J. M., Hall, L. E., Haggerty, D. J., Cooper, J. T., Golden, C. J., \& Dornheim, L. (1998). Development and validation of a measure of emotional intelligence. Personality and Individual Differences, 25, 167-177.

Sims-Vanzant, C. (2007). "Emotional Intelligence and Leadership Practices among Human Service Program Managers", University of San Francisco, 1-113.

Sinclair-Hunt, M., \& Simms, H. (2005). Organisational behaviour and change management. Cambridge: University of Cambridge International Examinations

Singh, D. (2003). Emotional Intelligence at Work: A Professional Guide (2nd Edition). New Delhi: Sage Publications.

Wang, J. (2011). "Understanding managerial effectiveness: a Chinese perspective", Journal of European Industrial Training, Vol. 35 Iss: 1, 6 - 23 